\title{
Fermentasi Kitin dari Limbah Cangkang Kepiting Menggunakan Jamur Rhizopus Oryzae pada Berbagai Kadar Air
}

\section{Retno Dwi Jayanti, Unung Leoanggraini*}

\begin{tabular}{l} 
I N F O A R T I K E L \\
\hline Diterima 26 Februari 2020 \\
Disetujui 15 April 2020 \\
\\
\hline Key word: \\
Chitin \\
Crab shell waste \\
Rhizopus oryzae \\
Water content \\
\hline Kata kunci: \\
Cangkang kepiting \\
Kadar air \\
Kitin \\
Rhizopus oryzae
\end{tabular}

*e-mail: Ununglz@yahoo.com *Telp: 08172345672

\begin{abstract}
A B S T R A T
Chitin on crab shell waste can be obtained by fermentation process use Rhizopus oryzae. The objective of this research are to determine the optimum of water content on crab shell waste fermentation by Rhizopus oryzae for chitin production. Fermentation process is carried out for 72 hours, 5 of $\mathrm{pH}, 37^{\circ} \mathrm{C}$, and $10 \%(\mathrm{v} / \mathrm{w})$ of inoculum addition. Water content on fermentation process were varried whithin $40 \%$, $50 \%$, and $60 \%$ respectively. Fermentation process were carried out by $40 \%$ of water content reported as the optimum based on the deproteinization degree and the solubility in acidic solution.

Chitin on crab shell waste can be obtained by fermentation process use Rhizopus oryzae. The objective of this research are to determine the optimum of water content on crab shell waste fermentation by Rhizopus oryzae for chitin production. Fermentation process is carried out for 72 hours, 5 of $p H, 37^{\circ} \mathrm{C}$, and $10 \%(v / w)$ of inoculum addition. Water content on fermentation process were varried whithin $40 \%$, $50 \%$, and $60 \%$ respectively. Fermentation process were carried out by $40 \%$ of water content reported as the optimum based on the deproteinization degree and the solubility in acidic solution.
\end{abstract}

\section{A BSTRAK}

Kitin pada limbah cangkang kepiting dapat diperoleh melalui proses fermentasi menggunakan jamur Rhizopus oryzae. Penelitian ini bertujuan untuk mengetahui kadar air optimum pada fermentasi limbah cangkang kepiting dengan Rhizopus oryzae untuk menghasilkan kitin. Fermentasi dilakukan pada kondisi operasi $\mathrm{pH} 5$ selama 72 jam pada suhu $37^{\circ} \mathrm{C}$ dengan penambahan inokulum sebesar $10 \%$ (v/b). Variasi kadar air yang digunakan untuk fermentasi yaitu $40 \%, 50 \%$, dan $60 \%$. Kadar air $40 \%$ pada proses fermentasi dilaporkan merupakan kadar air optimum yang mampu menghasilkan kitin berdasarkan derajat deproteinasi dan kelarutannya pada larutan asam.

\section{Pendahuluan}

Cangkang kepiting merupakan limbah yang dihasilkan dari proses pengolahan daging kepiting beku yang diekspor. Indonesia merupakan salah satu dari empat negara pengekspor kepiting di dunia [1]. Limbah yang dihasilkan dari kepiting daging beku yang diekspor berupa kepala dan cangkang kepiting sebesar 66.000 ton [2]. Banyaknya kepiting yang diekspor dan diolah juga mengakibatkan sisa limbah cangkang kepiting yang dapat mencemari lingkungan [3], [4] karena mudah membusuk akibat aktivitas mikroorganisme [5].

Limbah cangkang kepiting dapat diolah menjadi kitosan melalui proses deasetilasi kitin baik secara kimiawi maupun fermentasi [6] [3]. Proses sintesis kitosan secara kimiawi diawali 
dengan ekstraksi kitin yang melalui 2 proses, yaitu demineralisasi dan deproteinasi [6] kemudian dilanjutkan dengan proses deasetilasi. Ekstraksi kitin secara kimiawi pada proses demineralisasi dan deproteinasi umumnya menggunakan asam kuat sedangkan proses deasetilasi umumnya menggunakan basa kuat [4]. Proses kimiawi pada ekstraksi kitin dapat menyebabkan hidrolisis polimer kitin sehingga berakibat pada ketidak konsistenan produk akhir yang dihasilkan [6]. Penggunaan bahan kimia pada proses ekstraksi kitin juga dapat menimbulkan masalah pencemaran lingkungan yang membutuhkan biaya untuk mengatasinya [4], [7]. Oleh karena itu, fermentasi merupakan alternatif proses produksi kitosan yang ramah lingkungan karena memanfaatkan aktivitas mikroorganisme [8], [9].

Ekstraksi cangkang kepiting menjadi kitin secara fermentasi dapat dilakukan dengan menggunakan enzim kitinase yang dapat menghidrolisis senyawa kitin [9]. Enzim kitinase dapat dihasilkan dari berbagai mikroorganisme, yaitu Bacillus subtilis, Aeromonas sp, Pseudomonomas sp, Bacillus sp, Serratia sp [10], Rhizopus oryzae, Z.rouxii dan Lentinus edodes [11]. Kitin memiliki aplikasi luas dalam berbagai bidang, antara lain di industri pangan, farmasi, kosmetik, kedokteran, dan lainnya [12].

Penelitian mengenai produksi kitin secara fermentasi khususnya menggunakan jamur Rhizopus oryzae telah dilakukan oleh beberapa peneliti [8], [9], [13]. Akan tetapi, masih sedikit kajian pustaka mengenai fermentasi limbah cangkang kepiting menggunakan Rhizopus oryzae. Fermentasi padat dibatasi oleh kadar air hanya sekitar 30-80\% [14]. Oleh karena itu, penelitian ini bertujuan untuk menentukan kadar air optimum yang diperlukan pada proses fermentasi padat untuk memproduksi kitin dengan menggunakan Rhizopus oryzae.

\section{Bahan dan Metode}

\section{Persiapan Bahan Baku}

Limbah cangkang kepiting yang digunakan pada penelitian ini diperoleh dari Restoran Seafood HDL 293 Cilaki, Bandung. Bahan baku limbah cangkang kepiting yang digunakan dalam proses fermentasi memerlukan perlakuan awal terlebih dahulu dengan cara pencucian, pengeringan, pengecilan ukuran, dan pengayakan. Proses pencucian dilakukan dengan menggunakan air untuk menghilangkan kotoran yang masih menempel pada cangkang kepiting. Pengeringan dilakukan di dalam oven pada suhu $55^{\circ} \mathrm{C}-65^{\circ} \mathrm{C}$ sampai diperoleh berat yang konstan. Setelah itu dilakukan proses pengecilan ukuran dan pengayakan pada ukuran $0.5 \mathrm{~mm}$. Proses pengecilan ukuran limbah kepiting kering dilakukan dengan menggunakan blender sedangkan pengayakan dilakukan dengan menggunakan ayakan ukuran $0.5 \mathrm{~mm}$. Bahan baku yang lolos ukuran $0.5 \mathrm{~mm}$ kemudian dianalisis untuk menentukan kadar air, kadar protein, dan kadar mineral.

\section{Persiapan Inokulum}

Tahap persiapan inokulum diawali dengan proses pembuatan media dengan mencampurkan PDB (Potato Dextrose Broth) dengan aquades ke dalam Erlenmeyer kemudian dipanaskan diatas hot plate dan dihomogenkan dengan magnetic stirrer. Setelah campuran mendidih, media PDB dituang ke dalam tabung reaksi kemudian dilanjutkan dengan proses sterilisasi menggunakan autoklaf pada suhu $121^{\circ} \mathrm{C}$ selama 15 menit. Kultur murni jamur Rhizopus oryzae yang diperoleh dari Laboratorium Mikrobiologi, Fakultas SITH, Institut Teknologi Bandung, diinokulasi ke dalam media PDB kemudian diinkubasi pada suhu $37^{\circ} \mathrm{C}$ selama 3-4 hari. Inokulasi dilakukan secara aseptis.

3. Fermentasi

Proses fermentasi dilakukan dengan menggunakan tepung cangkang kepiting sebanyak 100 gram yang ditambah nutrisi yaitu $\mathrm{KH}_{2} \mathrm{PO}_{4} 0.09$ gam, $\mathrm{MgSO}_{4} 0.045$ gram, dan $\left(\mathrm{NH}_{4}\right)_{2} \mathrm{SO}_{4} 0.36$ gram, dilarutkan dengan sejumlah air untuk mencapai kadar air tepung cangkang kepiting sebesar $40 \%, 50 \%$, dan $60 \%$ setelah penambahan inokulum, kemudian dilakukan proses fermentasi. Proses fermentasi dilakukan selama 72 jam dengan pengambilan sampel setiap 24 jam dan $\mathrm{pH}$ sampel diukur menggunakan $\mathrm{pH}$ meter. Setelah proses fermentasi berakhir, dilakukan recovery produk yang diawali dengan sntrifugasi, pencucian, penyaringan, dan pengeringan. 
Sentrifugasi dilakukan untuk memisahkan filtrat dan endapan yang mengandung kitin. Pencucian endapan dilakukan dengan menggunakan aquadest sampai mencapai $\mathrm{pH}$ netral. Endapan hasil pencucian kemudian disaring dan dipanaskan di dalam oven pada suhu $55^{\circ} \mathrm{C}-65^{\circ} \mathrm{C}$ selama 48 jam kemudian dilakukan analisis.

\section{Analisis}

Proses analisis dilakukan terhadap bahan baku dan produk hasil fermentasi. Analisis yang dilakukan meliputi kadar air, kadar abu, kadar protein, dan uji kelarutan serta analisis gugus fungsi pada produk menggunakan FTIR.

\section{Hasil dan Pembahasan}

Bahan baku limbah cangkang kepiting yang telah diolah menjadi serbuk cangkang kepiting kering yang lolos ayakan $0.5 \mathrm{~mm}$ memiliki komposisi sebagaimana ditunjukkan oleh Tabel 1.

Tabel 1. Komposisi serbuk cangkang kepiting kering

\begin{tabular}{ll}
\hline Komposisi & Besarnya (\%) \\
\hline Air & 7.64 \\
Mineral & 61.44 \\
Protein & 41.79 \\
\hline
\end{tabular}

Hasil analisis proksimat terhadap bahan baku tersebut tidak sesuai dengan hasil penelitian Hajji et al., [4] karena perbedaan jenis kepiting yang digunakan. Kitin pada limbah cangkang kepiting terdapat dalam susunan jaringan protein kompleks dengan kalsium karbonat untuk membentuk cangkang yang kuat [1]. Interaksi antara kitin dan protein sangat kuat dan hanya sebagian kecil fraksi protein yang terkandung pada kompleks polisakarida-protein [15]. Oleh karena itu, untuk mengekstraksi kitin dari limbah cangkang kepiting memerlukan pengurangan dua molekul utama penyusun cangkang, yaitu protein, yang dikenal sebagai proses deproteinasi dan kalsium karbonat, yang dikenal sebagai proses demineralisasi [16]. Penelitian ini menggunakan fermentasi oleh Rhizopus oryzae untuk menurunkan kadar protein dan mineral sehingga diperoleh produk akhir berupa kitin.

Fermentasi kitin menggunakan Rhizopus oryzae didasarkan pada pemanfaatan protein yang terhidrolisis menjadi asam amino sebagai sumber nitrogen untuk pertumbuhan jamur sehingga mengakibatkan penurunan $\mathrm{pH}$ pada media fermentasi. Perubahan $\mathrm{pH}$ yang terjadi pada proses ekstraksi kitin secara fermentasi dengan variasi kadar air diamati pula pada penelitian ini. Hasil pengamatan tersebut ditunjukkan pada Gambar 1.

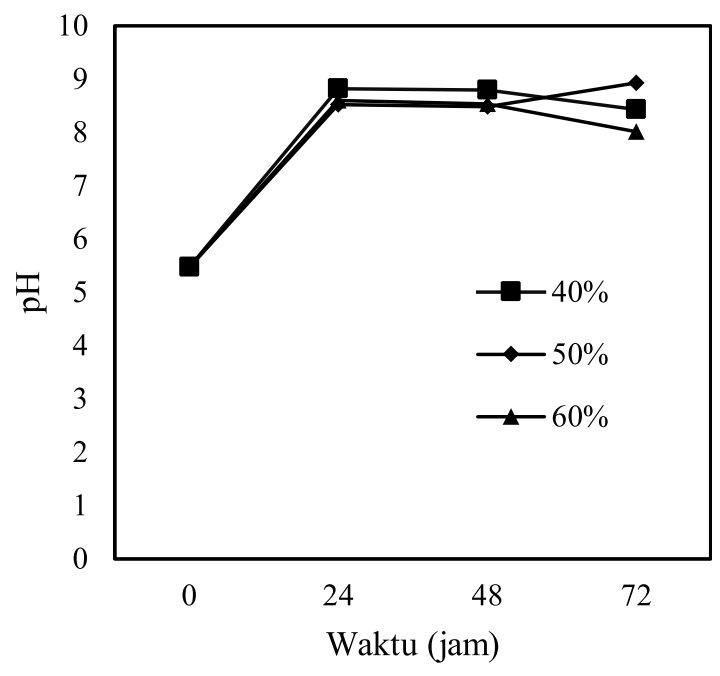

Gambar 1. Perubahan $\mathrm{pH}$ selama fermentasi dengan variasi kadar air

Berdasarkan Gambar 1, proses fermentasi menggunakan Rhizopus oryzae menunjukkan peningkatan $\mathrm{pH}$ selama 24 jam dan tidak berubah secara signifikan pada jam-jam berikutnya. Oleh karena itu, pada akhir fermentasi, $\mathrm{pH}$ kitin yang dihasilkan terdapat pada kisaran 8-9. Hal ini sesuai dengan penelitian sebelumnya yang dilakukan oleh Hajji et al., [4] dimana selama proses fermentasi terjadi peningkatan $\mathrm{pH}$ dari 7 menjadi 7.5 - 9.01

Proses ekstraksi kitin menggunakan fermentasi dengan bantuan mikroorganisme merupakan metode yang lebih sederhana, lebih produktif, dan lebih ramah lingkungan dibandingkan dengan proses ektraksi secara kimia. Proses demineralisasi dan deproteinasi pada pada fermentasi kitin terjadi secara simultan, meskipun memiliki efisiensi yang rendah pada beberapa kasus [5]. Produk kitin pada penelitian ini memiliki derajat demineralisasi dan deproteinasi sesuai dengan yang ditunjukkan pada Tabel 2. Nilai negatif pada derajat demineralisasi dan deproteinasi menunjukkan adanya peningkatan kadar mineral dan protein setelah proses fermentasi. 
Hasil fermentasi dengan kadar air 50\% mengalami peningkatan protein sedangkan peningkatan kadar protein dan mineral setelah fermentasi terjadi pada kadar air 60\%. Adanya peningkatan kadar protein pada hasil fermentasi ini disebabkan oleh adanya protein yang terdapat pada biomassa sel yang merupakan hasil dari pertumbuhan jamur. Derajat demineralisasi tertinggi diperoleh pada kadar air 40\%. Penelitian yang dilakukan oleh Andriana melaporkan bahwa proses demineralisasi maksimal terjadi pada kadar air yang rendah. Hasil derajat demineralisasi pada proses fermentasi ditunjukkan pada Tabel 2.

Fermentasi kitin terhadap produk limbah hasil perikanan dapat dibagi menjadi dua jenis, yaitu proses fermentasi melalui jalur asam laktat dan melalui jalur enzim protease. Jamur Rhizopus oryzae selain mampu memproduksi asam laktat juga mampu menghasilkan enzim protease. Asam laktat yang dihasilkan digunakan untuk proses demineralisasi. Fermentasi yang berlangsung menggunakan enzim protease dilaporkan kurang maksimal dalam proses demineralisasi ketika $\mathrm{pH}$ fermentasi diatas 8 [17]. Hasil derajat demineralisasi pada proses fermentasi ditunjukkan pada Tabel 2

Tabel 2. Nilai Derajat Demineralisasi pada berbagai kadar air

\begin{tabular}{ccc}
\hline $\begin{array}{c}\text { Kadar } \\
\text { air (\%) }\end{array}$ & $\begin{array}{c}\text { Derajat } \\
\text { demineralisasi } \\
(\mathbf{\%})\end{array}$ & $\begin{array}{c}\text { Derajat } \\
\text { deproteinasi } \\
\mathbf{( \% )}\end{array}$ \\
\hline 40 & 3.92 & 62.17 \\
50 & 3.34 & -1.29 \\
60 & -4.99 & -8.64 \\
\hline
\end{tabular}

Kitin yang masih terdapat pada kompleks protein-polisakarida yang terikat di dalam senyawa penyusun cangkang kepiting tidak dapat larut di dalam air pada suhu kamar. Uji kelarutan pada penelitian ini bertujuan untuk membandingkan kelarutan bahan baku dan kelarutan kitin di dalam pelarut akuades, asam asetat, dan $\mathrm{HCl}$. Tabel 3 menunjukkan peningkatan kelarutan kitin sebelum dan sesudah dilakukan proses fermentasi. Kelarutan kitin tertinggi pada pelarut terjadi pada kadar air 40\%. Hal ini dapat diduga kadar air optimum untuk menghasilkan kitin secara fermentasi pada penelitian ini yaitu $40 \%$ berdasarkan derajat demineralisasi, deproteinasi dan kelarutan.

Penelitian mengenai pengaruh kadar air terhadap proses fermentasi kitin dari limbah cangkang kepiting juga telah dilakukan oleh Andriyana [18]. Hasil penelitian menyebutkan bahwa proses fermentasi dengan rasio bahan baku terhadap air sebesar 1:1.5 menghasilkan kitin sebesar 53.73\%. Kadar air tersebut merupakan kadar air terendah yang digunakan pada penelitian.

Tabel 3. Kelarutan kitin dalam berbagai pelarut

\begin{tabular}{cccc}
\hline \multirow{2}{*}{$\begin{array}{c}\text { Variasi } \\
\text { kadar air } \\
\mathbf{( \% )}\end{array}$} & $\begin{array}{c}\text { Asam } \\
\text { asetat } \\
\mathbf{( 2 \% )}\end{array}$ & Akuades & $\begin{array}{c}\mathbf{H C l} \\
\mathbf{( 0 . 5 \% )}\end{array}$ \\
\cline { 2 - 4 } 40 & 46.94 & 11.96 & 39.91 \\
50 & 50.83 & 9.29 & 37.56 \\
60 & 45.88 & 8.64 & 34.58 \\
$\begin{array}{c}\text { Bahan } \\
\text { baku }\end{array}$ & 46.65 & 8.05 & 20.59 \\
\hline
\end{tabular}

Analisis gugus fungsi menggunakan FTIR bertujuan untuk membandingkan struktur kitin hasil fermentasi dengan strukur kitin komersial. Hasil analisis FTIR ditunjukkan pada Gambar 2, dimana ketiga senyawa kitin hasil fermentasi pada berbagai kadar air menunjukkan kesamaan pola pita-pita serapan pada bilangan gelombang $3500 \mathrm{~cm}^{-1}$ sampai 900 $\mathrm{cm}^{-1}$. Adanya kitin ditandai dengan munculnya pita serapan pada bilangan gelombang 1600 $\mathrm{cm}^{-1}$ sampai $1500 \mathrm{~cm}^{-1}$ yang merupakan gugus amida I. Hasil FTIR pada penelitian ini sama dengan hasil dari penelitian yang dilakukan oleh Fernando et al., [12] Pita serapan yang lebar pada bilangan gelombang $3500 \mathrm{~cm}^{-1}$ yang terdapat pada hasil fermentasi dengan kadar air $50 \%$ dan $60 \%$ merupakan gugus $\mathrm{OH}$ pada air. Hal ini menunjukkan bahwa kitin pada kedua produk tersebut mengikat air lebih banyak dibandingkan dengan produk kitin dengan kadar air $40 \%$. Oleh karena itu, analisis gugus fungsi pada produk kitin dengan kadar air 40\% (Gambar 3) lebih mendekati pola gugus 
fungsi pada senyawa kitin murni dibanding produk kitin dengan kadar air 60\% (Gambar 4).

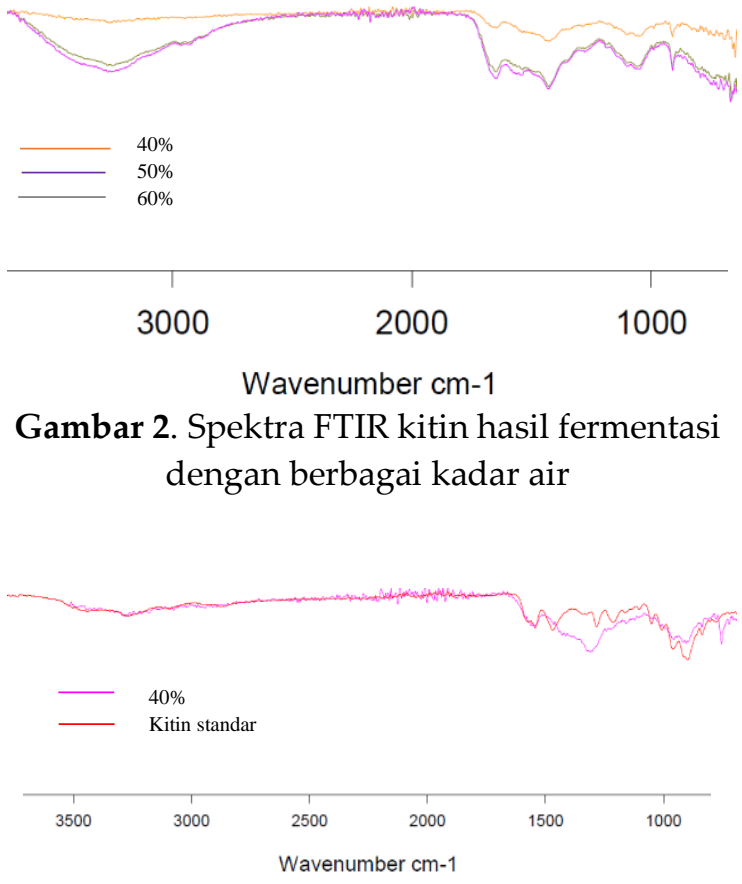

Gambar 3. Perbandingan spektra FTIR produk kitin (kadar air fermentasi 40\%) dengan kitin standar

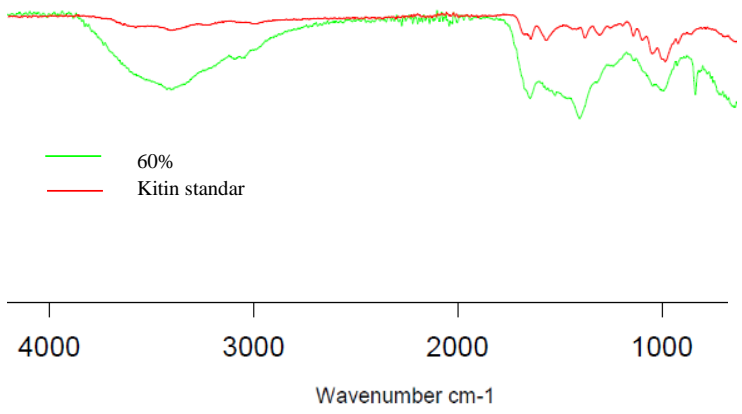

Gambar 4. Perbandingan spektra FTIR produk kitin (kadar air fermentasi 60\%) dengan kitin standar

\section{Ucapan terimakasih}

Peneliti mengucapkan terima kasih kepada Unit Penelitian dan Pengabdian Masyarakat (UUPM) Politeknik Negeri Bandung yang telah mendanai penelitian ini melalui dana DIPA Polban.

\section{Kesimpulan}

Kadar air optimum pada proses fermentasi limbah cangkang kepiting menggunakan Rhizopus oryzae untuk menghasilkan kitin pada penelitian ini adalah
40\%. Hal ini ditunjukkan dengan tingginya derajat deproteinasi $(62.17 \%)$, derajat demineralisasi (3.92\%), dan kelarutan kitin tertinggi di dalam asam asetat yaitu $46.94 \%$. Oleh karena itu, dapat disimpulkan produksi kitin pada penelitian ini menggunakan metode fermentasi yaitu sebesar $46.94 \%$. Selain itu berdasarkan hasil analisis gugus fungsi menggunakan FTIR, produk kitin dengan kadar air 40\% memiliki kemiripan pola dengan snyawa kitin standar.

\section{Daftar Pustaka}

1. B. A. Cheba, T. I. Zaghloul, and A. R. ElMahdy, Demineralized crab and shrimp shell powder: Cost effective medium for bacillus Sp. R2 growth and chitinase production, Procedia Manuf., vol. 22, pp. 413-419, 2018.

2. L. Apriani, G. M. Iskandar, and M. Said, "Pengaruh variasi konsentrasi $\mathrm{NaOH}$ terhadap nilai derajat deasetilasi pada pembuatan chitosan dari cangkang kulit kepiting, J. Tek. Kim., vol. 18, no. 1, pp. 35-40, 2012.

3. C. Lopes, L. T. Antelo, A. Franco-Uría, A. A. Alonso, and R. Pérez-Martín, "Chitin production from crustacean biomass: Sustainability assessment of chemical and enzymatic processes, $J$. Clean. Prod., vol. 172, pp. 4140-4151, 2018.

4. S. Hajji, O. Ghorbel-Bellaaj, I. Younes, K. Jellouli, and M. Nasri, Chitin extraction from crab shells by Bacillus bacteria. Biological activities of fermented crab supernatants, Int. J. Biol. Macromol., vol. 79, pp. 167-173, 2015.

5. P. Beaney, J. Lizardi-Mendoza, and M. Healy, Comparison of chitins produced by chemical and bioprocessing methods, J. Chem. Technol. Biotechnol., vol. 80, no. 2, pp. 145-150, 2005.

6. H. El Knidri, R. Belaabed, A. Addaou, A. Laajeb, and A. Lahsini, Extraction, chemical modification and characterization of chitin and chitosan, Int. J. Biol. Macromol., vol. 120, pp. 11811189, 2018.

7. K. T. Oh, Y. J. Kim, V. N. Nguyen, W. J. Jung, and R. D. Park, Demineralization 
of crab shell waste by Pseudomonas aeruginosa F722, Process Biochem., vol. 42, no. 7, pp. 1069-1074, 2007.

8. O. C. Tasar, S. Erdal, and M. Taskin, Chitosan production by psychrotolerant Rhizopus oryzae in non-sterile open fermentation conditions, Int. J. Biol. Macromol., vol. 89, pp. 428-433, 2016.

9. S. Chatterjee, S. Chatterjee, B. P. Chatterjee, and A. K. Guha, Enhancement of growth and chitosan production by Rhizopus oryzae in whey medium by plant growth hormones, Int. J. Biol. Macromol., vol. 42, no. 2, pp. 120 126, 2008.

10. D. P. Sigres and A. Sutrisno, “Enzim mananase dan aplikasi di bidang industri: Kajian pustaka Mannanase and the Application in Industry: A Review," J. Pangan dan Agroindustri, vol. 3, no. 3, pp. 899-908, 2015.

11. W. Suntornsuk, P. Pochanavanich, and L. Suntornsuk, Fungal chitosan production on food processing byproducts, Process Biochem., vol. 37, no. 7, pp. 727-729, 2002.

12. L. A. T. Fernando, M. R. S. Poblete, A. G. M. Ongkiko, and L. J. L. Diaz, Chitin Extraction and Synthesis of ChitinBased Polymer Films from Philippine Blue Swimming Crab (Portunus pelagicus) Shells, Procedia Chem., vol. 19, pp. 462-468, 2016.

13. J. Sebastian, T. Rouissi, S. K. Brar, K. Hegde, and M. Verma, Microwaveassisted extraction of chitosan from Rhizopus oryzae NRRL 1526 biomass, Carbohydr. Polym., vol. 219, pp. 431-440, 2019.

14. E. Oriol, M. Raimbault, S. Roussos, and G. Viniegra-Gonzales, Water and water activity in the solid state fermentation of cassava starch by Aspergillus niger, Appl. Microbiol. Biotechnol., vol. 27, no. 5-6, pp. 498-503, 1988.

15. Y. Afriani, A. Fadli, S. Maulana, and I. Karina, PLL 07 Sintesis , Kinetika Reaksi dan Aplikasi Kitin dari Cangkang Udang: Review, no. October, pp. 1-2, 2016.

16. E. J. Dompeipen, Isolasi dan identifikasi kitin dan kitosan dari kulit udang windu (Penaeus monodon) dengan spektroskopi inframerah, Maj. BIAM, vol. 13, no. 1, pp. 31-41, 2017.

17. S. Kaur and G. S. Dhillon, Recent trends in biological extraction of chitin from marine shell wastes: A review, Crit. Rev. Biotechnol., vol. 35, no. 1, pp. 44-61, 2015.

18. I, Andriyana, 2017. Ekstraksi Kitin dari Limbah Cangkang Kepiting secara Fermentasi menggunakan bakteri Lactobacillus achidophillus. Tugas Akhir. Jurusan Teknik Kimia, Politeknik Negeri Bandung, Bandung. 